\title{
Floating Radioluminography
}

\author{
吉沢幸夫，古田悦子*，名竹孝志，澈上 誠 \\ 東京慈恵会医科大学アイソトープ実験施設 \\ 105 東京都港区西新橋 3-25-8 \\ *お茶の水女子大学理学部ラジオアイソトープ実験室 \\ 112 東京都文京区大塚 2-1-1 \\ 1995年10月25日 受理
}

\begin{abstract}
トリチウム $\left({ }^{3} \mathrm{H}\right)$ 用イメージングプレート (IP) の放射能污染を防止するために，放射性試料と IP を密着させることなく曝射する方法 (floating radioluminography) を提案する。これにより, 従来 困難とされてきた ${ }^{3} \mathrm{H}$ 用 IP の再使用が可能となる。さらに，IP への曝射を真空中で行うことにより， 検出感度がきわめて上昇することを明らかにした。
\end{abstract}

Key Words: phosphor screen imaging, radioluminography, tritium, liquid scintillation counter

\section{1. 緒言}

輝尽性発光体を塗布したイメージングプレー 卜（IP）に蓄積された放射線エネルギーをレー ザービームにより読み取るラジオルミノグラ フィ（RLG）は, 従来の X 線フィルムを用いる 方法に比較して高感度であり，しかも定量性が 良いという大きな特徵をあつ。さらに, 最近卜 リチウム $\left({ }^{3} \mathrm{H}\right)$ のようにきわめてエネルギーの 低い $\beta$ 線の測定を目的にした ${ }^{3} \mathrm{H}$ 用 IP が開発 され，医学・薬学・理学・工学の広い分野での 利用が発展しつつある ${ }^{1)-4)}$ 。

${ }^{3} \mathrm{H}$ 用 IP は発光体表面に保護膜が存在しない あので，使用に際しては低エネルギー $\beta$ 線の 空気層による吸収を避けるために, 測定試料と IP を直接密着して曝射させることが不可欠と されてきた。しかしながら，このような密着法 では多くの場合 IP の放射能污染が引き起こさ れる。このため ${ }^{3} \mathrm{H}$ 用 IP は高価であるにもか かわらず，消耗品とされてきた。

この問題点を解消するために, 試料と IP を 密着することなく曝射する方法 (floating radioluminography, FRLG)を考案した。この測 定法を用いると IP の ${ }^{3} \mathrm{H}$ 污染を避けることが できるので， ${ }^{3} \mathrm{H}$ 用 IP の再使用が可能となる。
また，IPへの曝射を真空中で行うことにより， 空気による $\beta$ 線の吸収を取り除くことができ るので, 試料-IP 間隔を $\beta$ 線の空気中飛程より 大きくできるだけでなく，検出感度がきわめて 上昇することを明らかにした。

\section{2. 方 法}

IP として ${ }^{3} \mathrm{H}$ 用 IP, 解析装置として BAS 2000 （富士写真フイルム(梸）を用いた。消去器によ り残像を消去した IP の上にスペーサを介して ${ }^{3} \mathrm{H}$ 線源を置き, 曝射後, 常法に従いデー夕解 析を行った。RLGでは, 得られる像を定量評 価するため，X線フィルムの黒化度に相当する 值として PSL (photostimulated luminescence）值が定義されている5)。

${ }^{3} \mathrm{H}$ 線源としてオートラジオグラフィ用標準 線源 ART-123(American Radiolabeled Chemicals Inc.)，アッセイプレート試料および薄層 クロマトグラム（TLC）試料を使用した。 ART-123 は $17.26 \mathrm{MBq} / \mathrm{g}$ から $4.96 \mathrm{kBq} / \mathrm{g}$ の 放射能濃度をもつプラスチック片（5 $\mathrm{mm} \times 7$ $\mathrm{mm}, 0.199 \mathrm{mg}$ ）をスライドグラスに固定した あのである。

真空中で曝射を行うための真空チェンバーと して超遠心機のローター室 (温度 $25^{\circ} \mathrm{C}$, 真空 


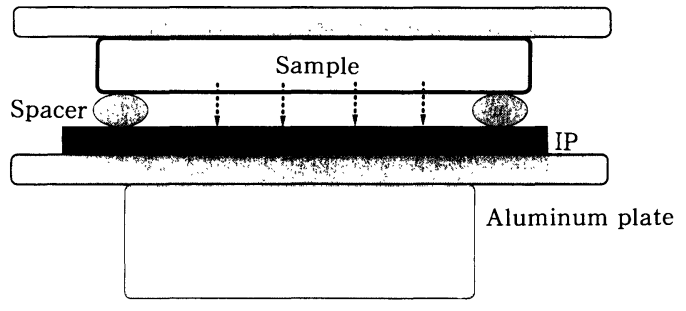

Fig. 1 Diagram of floating radioluminography.

度 $0.5 \mathrm{mPa}$ ）を使用した。ローター室は ${ }^{3} \mathrm{H}$ 用 IP サイズに比べ狭いので, IP $20 \mathrm{~cm} \times 25 \mathrm{~cm}$ と $20 \mathrm{~cm} \times 15 \mathrm{~cm}$ の 2 枚に切断して用いた。 ローター室にアルミ製の支持台を置き，その上 にアルミ板, IP, スペーサ, 試料, アルミ板の 順に重ねて置き曝射した (Fig. 1)。解析の際に はIP の裏面をスコッチテープで貼り合わせて 元の大きさに戻して測定した。

\section{3. 結果および考察}

${ }^{3} \mathrm{H}$ から放出される $\beta$ 線は $18.6 \mathrm{keV}$ の最大 エネルギーを有し, 空気中の飛程は $5 \mathrm{~mm}$ ほど にすぎない6)。このため ${ }^{3} \mathrm{H}$ 用 IP を使用して む，IP の污染防止のための保護フィルムを用 いることができない。この問題点を解消する手 段として，IP と測定試料を密着させることな く, 試料を浮かせて曝射した。さらに，真空中
で曝射を行うと空気による $\beta$ 線の吸収が無視 できるので検出感度が上昇するだけでなく, 解 像力を問題にしなければ試料-IP 間隔を ${ }^{3} \mathrm{H} \beta$ 線の空気中の最大飛程である $5 \mathrm{~mm}$ 以上に大 きくできる可能性がある。

スペーサとして厚さ $0.5 \mathrm{~mm}$ のシリコン シートを ART-123 と IP の間に挿入し, 真空 中あるいは大気中で 72 時間曝射後，常法に 従って読みとった。Fig. 2 に示したように, 真 空中では $1 \mathrm{~Bq}$ の ${ }^{3} \mathrm{H}$ まで検出可能であった。 得られた像の定量結果（Fig. 3) より，真空中 での測定結果と空気中でのそれと比較すると, 真空中では空気中に比べて PSL 值が 5 倍上昇 する。

医学・生物学研究などにおいては, 多数の試 料を処理するためにアッセイプレートが繁用さ れる7)。これらのプレートの深さは $5 \mathrm{~mm}$ 以上 あるので，ウェルの底面に捕集された ${ }^{3} \mathrm{H}$ 試料 の $\beta$ 線は空気層に吸収され，上面に IP を設置 しても検出できない。しかしながら，Fig.4に 示したように，真空中で曝射を行うことによ り，容易に検出される。Fig. 5 に示した定量結 果より，検出限界は $10 \mathrm{~Bq} /$ well と推定され る。ART-123 を測定した場合に比べ感度が低 いのは，プレートの底面積 $1 \mathrm{~cm}^{2}$ に比べ試料IP 間の距離が長く，また試料の自己吸収が大

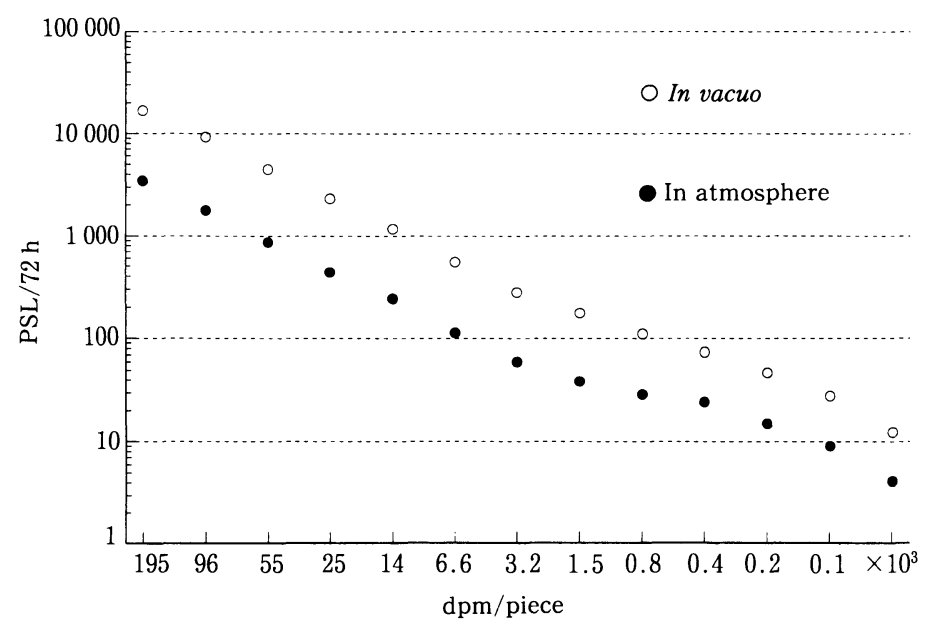

Fig. 3 Relationship between radioactivity and PSL value for ${ }^{3} \mathrm{H}$ standard sample set. 


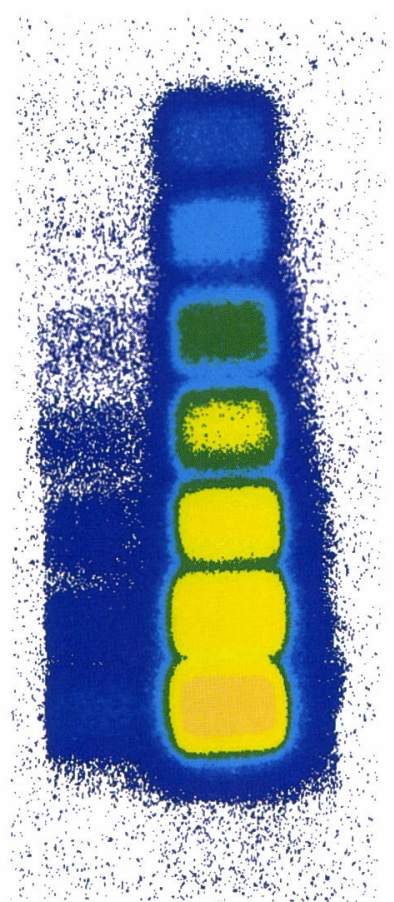

In vacuo

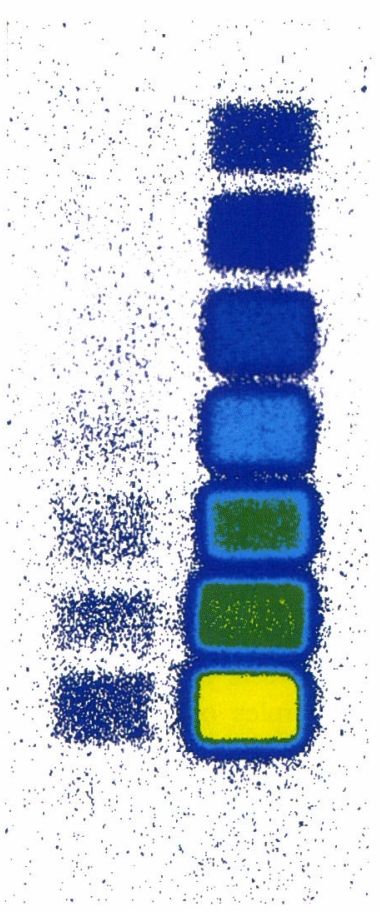

In atmosphere

Fig. 2 Radioluminograms of a series of ${ }^{3} \mathrm{H}$ standard sample set.

An IP was irradiated with an ART123 by using a $0.5 \mathrm{~mm}$ spacer for 72 $\mathrm{h}$ in vacuo and in atmosphere.

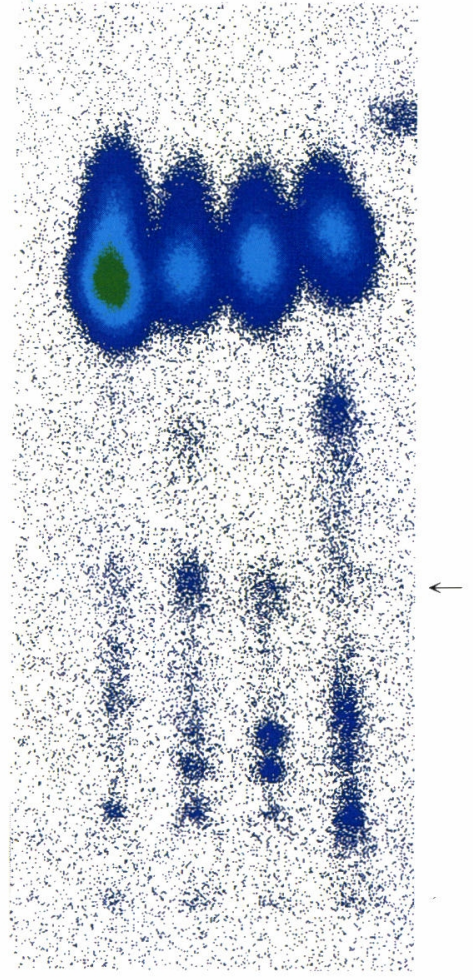

Fig. 6 Radioluminograms of a ${ }^{3} \mathrm{H}$-TLC plate. A TLC plate was exposed with an IP for $72 \mathrm{~h}$ in vacuo. $\leftarrow$ : Oleic acid

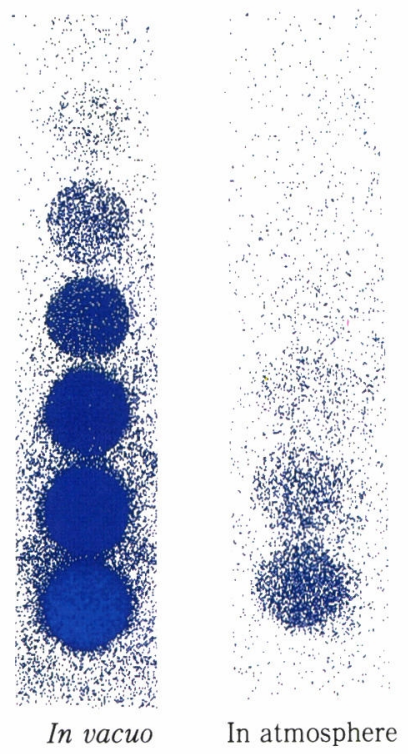

Fig. 4 Radioluminograms of ${ }^{3} \mathrm{H}$ samples in wells of a microplate.

Samples collected in the wells of the microplate were dried at room temperature, and exposed with an IP for $24 \mathrm{~h}$ in vacuo and in atmosphere. 


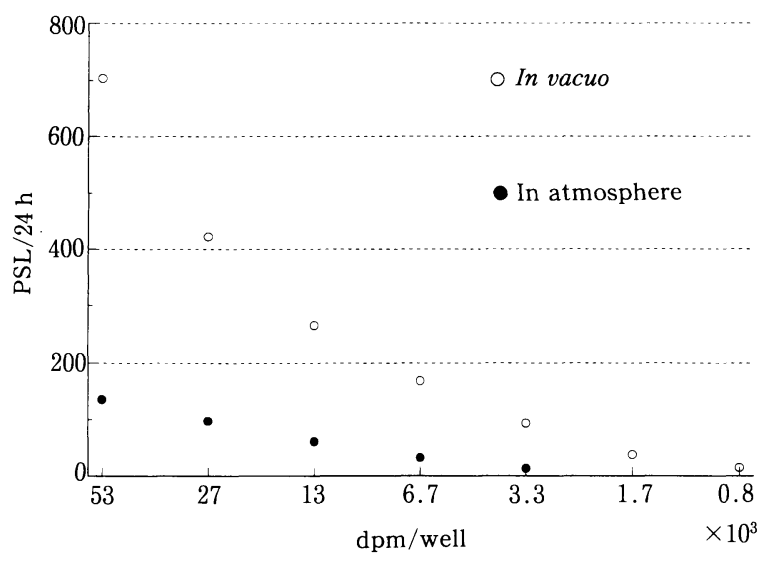

Fig. 5 Relationship between radioactivity and PSL value for ${ }^{3} \mathrm{H}$ samples collected in wells of a microplate.

きいためである。

本法の有効性を確かめるために ${ }^{3} \mathrm{H}-\mathrm{TLC}$ を floating radioluminography に適用した。 TLC は簡便，迅速な分析法であるにもかかわ らず， ${ }^{3} \mathrm{H}$ 標識化合物の検出が容易でないため, 溶媒抽出や高速クロマトグラフィにより分離精 製を行い，液体シンチレーションカウンタで定 量するという煩雑な方法が用いられてきた8)。 Fig. 6 は厚さ $0.34 \mathrm{~mm}$ の濾紙（ワットマン No.

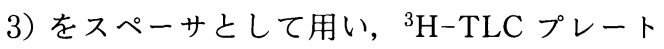
を真空中で曝射した結果である。目的とするオ レイン酸のバンドは 72 時間の曝射で検出され た。一方, 通常の $\mathrm{X}$ 線フィルムで本結果を得 るためには数週間の曝射時間を要するので, 本 法はきわめて迅速かつ操作が容易であることが 実証された。このバンドの形成に寄与した部分 のクロマトグラムを液体シンチレーション測定 装置で测定した結果は $200-500 \mathrm{cpm}$ であっ た。

以上の実験結果から, floating radioluminography の特徴は次のようにまとめることが できる。

（1）放射性試料による IP の污染を避けるこ とができるので, ${ }^{3} \mathrm{H}$ 用 IP の再使用が可能であ る。
(2) 真空中で曝射することにより, ${ }^{3} \mathrm{H} \beta$ 線 の空気中飛程以上の試料 - IP 間隔で曝射でき る。

(3) 真空中での曝射により検出感度が著しく 向上する。

、なお，本研究では真空系として超遠心機の ローター室を流用したが, 現在 IP 曝射用真空 チェンバーの作製を考案中である。

\section{文献}

1) Amemiya, Y. and Miyahara, J. : Nature, 336, 89-90 (1988)

2) Gong, Z. W. and Yoshizawa, Y.: Jikeikai Medical J., 42, 255-262 (1995)

3）宮原諒二：現代化学，223，29-36（1989）

4) Baba, S., Terazawa, Y., Kimata, H., Shinohara, Y., Akira, K. and Hasegawa, H. : J. Chromatography, A663, 35-41 (1995)

5）浜岡 勤：細胞工学，9，456-462（1990）

6) Mantel, J. : Int. J. Appl. Radiat. Isot., 23, 407413 (1972)

7) Baba, S., Kimata, H., Haruki, S. and Shinohara, Y. : Appl. Radiat. Isot., 44, 1011-1014 (1993)

8) Ida, H., Kusano, K., Suzuki, H., Tokoro, T. and Eto, Y. : Biochem. Biophys. Res. Commun., 166, 1053-1060 (1990) 


\section{Abstract}

\section{Floating Radioluminography}

Yukio Yoshizawa, Etsuko Furuta*, Takashi Natake and Makoto Takiue

Radioisotope Research Center, The Jikei University School of Medicine,

3-25-8, Nishishimbashi, Minato-ku, Tokyo 105, Japan

*Radioisotope Laboratory, Faculty of Science, Ochanomizu University,

2-1-1, Otsuka, Bunkyo-ku, Tokyo 112, Japan

A new technique of phosphor screen imaging has been proposed. The floating radioluminography can be approached by exposing the imaging plate (IP) without bringing into contact with a radioactive sample. Thus, since it can be free from the radioactive contamination, we can employ the ${ }^{3} \mathrm{H}-I P$ repeatedly. Moreover, when the exposure to the IP is held in a vacuum, the detection sensitivity can be greatly enhanced.

(Received October 25, 1995) 